\title{
Association between systemic activity index and dry eye severity in patients with primary Sjögren syndrome
}

\author{
A associação entre o índice de atividade sistêmica e a severidade do olho \\ seco em pacientes com síndrome de Sjögren primária
}

\author{
Dilay Ozek', Ozlem Evren Kemer', Ahmet Omma² \\ 1. Department of Ophthalmology, Ankara Numune Education and Research Hospital, Turkey. \\ 2. Department of Rheumatology, Ankara Numune Education and Research Hospital, Turkey.
}

\begin{abstract}
Purpose: The aim of the present study was to compare the severity of ocular and systemic findings among patients with primary Sjögren syndrome. Methods: The study followed a prospective controlled design and comprised two groups; the test group included 58 eyes of 58 patients newly diagnosed with primary Sjögren syndrome with poor dry eye test findings and the control group included 45 right eyes of 45 healthy age- and sex-matched individuals. The ocular surface disease index score, tear osmolarity, Schirmer I test without anesthesia, fluorescein tear breakup time, and cornea-conjunctiva staining with lissamine green (van Bijsterveld scoring) were used to examine tear function in the patients via a complete ophthalmological examination. The results were graded and classified on the basis of a Dry Eye WorkShop report and results of the corneal and conjunctival staining test, Schirmer's test, and fluorescein tear breakup time test. Discomfort, severity and frequency of symptoms, visual symptoms, conjunctival injection, eyelid-meibomian gland findings, and corneal-tear signs were interpreted. Disease activity was scored per the EULAR Sjögren's syndrome disease activity index (ESSDAl) via systemic examination and laboratory evaluations, and the EULAR Sjögren's syndrome patient-reported index (ESSPRI) assessed via a survey of patient responses. Results: Mean patient age was $48.15 \pm 16.34$ years in the primary Sjögren syndrome group and $44.06 \pm 9.15$ years in the control group. Mean fluorescein tear breakup time was $4.51 \pm 2.89 \mathrm{~s}$ in the primary Sjögren syndrome group and $10.20 \pm 2.39 \mathrm{~s}$ in the control group. Mean Schirmer I test result was $3.51 \pm 3.18 \mathrm{~mm} / 5 \mathrm{~min}$ in the primary Sjögren syndrome group and $9.77 \pm 2.30 \mathrm{~mm} / 5 \mathrm{~min}$ in the control group.
\end{abstract}

Submitted for publication: January 28, 2018

Accepted for publication: June 3, 2018

Funding: No specific financial support was available for this study.

Disclosure of potential conflicts of interest: None of the authors have any potential conflicts of interest to disclose.

Corresponding author: Dilay Ozek

Dumlupinar Bulvari 364/B D.24 - Ankara, Turkey - E-mail: dilaytop@gmail.com

Approved by the following research ethics committee: Ankara Numune Education and Research Hospital (\# E-17-1531).
Mean ocular surface disease index score was $18.56 \pm 16.09$ in the primary Sjögren syndrome group, and $19.92 \pm 7.16$ in the control group. Mean osmolarity was $306.48 \pm 19.35$ in the primary Sjögren syndrome group, and $292.54 \pm 10.67$ in the control group. Mean lissamine green staining score was $2.17 \pm$ 2.76 in the primary Sjögren syndrome group, and 0.00 in the control group. Statistically significant differences were found berween the primary Sjögren syndrome group and control group in terms of fluorescein tear breakup time, Schirmer's test, lissamine green staining, and osmolarity tests $(p=0.036, p=0.041$, $p=0.001$, and $p=0.001$ respectively). The Dry Eye WorkShop score was $2.15 \pm 0.98$, the EULAR Sjögren's syndrome disease activity index score was $11.18 \pm 4.05$, and the EULAR Sjögren's syndrome patient-reported index score was $5.20 \pm 2.63$. When potential associations of the Dry Eye Workshop Study scores and osmolarity scores with the Eular Sjögren's syndrome disease activity index scores were evaluated, the results were found to be statistically significant ( $p=0.001, p=0.001$ respectively). Conclusion: The results showed an association between dry eye severity and systemic activity index in primary Sjögren syndrome patients.

Keywords: Sjögren syndrome; Dry eye syndromes; Severity of illness index

RESUMO | Objetivo: O objetivo do presente estudo foi comparar a gravidade dos achados oculares e sistêmicos entre pacientes com síndrome de Sjögren primária. Métodos: O estudo seguiu um delineamento prospectivo controlado e compreendeu dois grupos; o grupo de teste incluiu 58 olhos de 58 pacientes recém-diagnosticados com síndrome de Sjögren primária com resultados deficientes no teste de olho seco e o grupo controle incluiu 45 olhos direitos de 45 indivíduos saudáveis pareados idade e sexo. A contagem do índice de doença da superfície ocular, osmolaridade lacrimal, teste de Schirmer I sem anestesia, tempo de ruptura da fluoresceína e coloração córnea-conjuntiva com verde de lissamina (índice de van Bijsterveld) foram utilizados para examinar a função lacrimal dos pacientes através de exame oftalmológico completo. Os resultados foram classificados com base em um relatório da "Dry Eye Workshop" e resultados do 
teste de coloração da córnea e conjuntiva, teste de Schirmer e teste do tempo de ruptura da fluoresceína. Desconforto, gravidade e frequência dos sintomas, sintomas visuais, injeção conjuntival, achados das glândulas palpebrais e sinais da córnea foram interpretados. A atividade da doença foi avaliada pelo índice de atividade da doença da síndrome de Sjögren EULAR por meio de exame sistêmico e avaliações laboratoriais, e o índice relatado pelo paciente da síndrome de Sjörgen EULAR avaliado através de uma pesquisa das respostas dos pacientes. Resultados: A média de idade dos pacientes foi de 48,15 \pm 16,34 anos no grupo da Síndrome de Sjörgen primária e 44,06 $\pm 9,15$ anos no grupo controle. O tempo médio de ruptura da fluoresceína foi de 4,51 $\pm 2,89$ s no grupo síndrome de Sjögren primária e 10,20 $\pm 2,39$ s no grupo controle. O resultado do teste de Schirmer I médio foi de 3,51 $\pm 3,18 \mathrm{~mm} / 5 \mathrm{~min}$ no grupo síndrome de Sjögren primária e de 9,77 $\pm 2,30 \mathrm{~mm} / 5 \mathrm{~min}$ no grupo controle. O índice médio de doença da superfície ocular foi de 18,56 \pm 16,09 no grupo síndrome de Sjögren primária e 19,92 $\pm 7,16$ no grupo controle. A osmolaridade média foi 306,48 \pm 19,35 no grupo síndrome de Sjögren primária e 292,54 $\pm 10,67$ no grupo controle. O resultado médio de coloração com lissamina verde foi de 2,17 \pm 2,76 no grupo síndrome de Sjögren primária e 0,00 no grupo controle. Diferenças estatisticamente significativas foram encontradas entre o com síndrome de Sjögren primária e o grupo controle em termos de tempo de ruptura da fluoresceína lacrimal, teste de Schirmer l, coloração com lissamina verde e osmolaridade $(p=0,036$, $p=0,041, p=0,001, p=0,001$ respectivamente). O índice Estudo do Olho Seco foi de 2,15 $\pm 0,98$, o índice de atividade da doença da síndrome de Sjögren EULAR foi de 11,18 \pm 4,05 e a pontuação do índice relatado pelo paciente EULAR Sjögren foi de 5,20 $\pm 2,63$. Quando associações potenciais do Estudo do Olho Seco e o índice da osmolaridade foram comparados a pontuação de índice de atividade da doença da síndrome de Sjögren EULAR, os resultados foram estatisticamente significantes ( $p=0,001, p=0,001$ respectivamente). Conclusão: Os resultados mostraram uma associação entre a gravidade do olho seco e o índice de atividade sistêmica em pacientes com síndrome de Sjögren primária.

Descritores: Síndrome de Sjögren; Síndromes do olho seco; Índice de gravidade de doença

\section{INTRODUCTION}

Dry eye may cause potential damage to the ocular surface, and is associated with tear instability, visual problems, and discomfort, constituting a multifactorial disorder of the ocular surface. Tear osmolarity is increased and inflammation is observed on the ocular surface ${ }^{(1)}$.

Dry eye was described in a report in 2017 as "A multifactorial disease of the ocular surface characterized by a loss of homeostasis of the tear film, and accompanied by ocular symptoms in which tear film instability and hyperosmolarity, ocular surface inflammation and damage, and neurosensory abnormalities play an etiological role"(2).

Dry eye is a defect of the lacrimal functional unit that includes the lacrimal gland, the ocular surface (conjunctiva, cornea, and meibomian gland), the eyelid, and the sensory and motor nerves connecting them ${ }^{(3)}$.

This functional unit controls the main components of the tear film in a regulated form and responds to environmental, endocrinological, and cortical effects. Its general function is to maintain the integrity of the tear film, the transparency of the cornea, and the quality of the image reflected on the retina ${ }^{(3-5)}$.

Dry eye is examined in two parts etiopathologically, as evaporative and aqueous tear deficiency. Both are lacrimal functional unit disorders. Aqueous tear deficiency is a condition in which lacrimal secretion in the lacrimal glands is inadequate. When adequate tears cannot be produced, osmolarity and inflammation develop on the ocular surface ${ }^{(6)}$. Aqueous tear deficiency is categorised in two groups as Sjögren syndrome and Non-Sjögren syndrome.

Sjögren's syndrome is systemic disease in which lymphocyte infiltration into the exocrine glands damages the salivary gland and the lacrimal gland resulting in the development of dry eyes and dry mouth. This inflammatory process can also involve synovitis; vasculitis; and skin, lung, kidney, and neuronal systems ${ }^{(7-9)}$. Sjögren's syndrome aloneis referred to as primary Sjögren syndrome (PSS), and when accompanied by other autoimmune diseases such as systemic erythromatosis and rheumatoid arthritis, it is known as secondary Sjögren syndrome $(\mathrm{SSS})^{(10-11)}$. Auto-antibodies such as antinuclear antibody, Ro/SSA, La/SSB are detected in the serum of patients because PSS is an autoimmune disease ${ }^{(12)}$. Inflammatory mediators in the tear film and conjunctiva in PSS cause hyposecretion due to inflammation in the lacrimal gland and cause dry eye $\mathrm{e}^{(13)}$.

In the present study, results of dry eye tests in PSS patients were classified based on a Dry Eye WorkShop (DEWS) report ${ }^{(14)}$ using fluorescein breakup time (FBUT) test, Schirmer I test and lissamine green staining scores, and evaluation of discomfort, severity and frequency symptoms, visual symptoms, conjunctival injection, eyelid-meibomian gland findings, and corneal-tear signs; the EULAR Sjögren's syndrome disease activity index (ESSDAl) scoring system was also used to assess systemic disease activity. Considering the results of a comprehensive ESSDAl-correlated DEWS and literature searches, the present study 
is the first to evaluate both visual and systemic activity. We investigated whether or not ocular surface status was correlated with systemic activity of the PSS.

\section{METHODS}

The study was conducted in accordance with the principles of the Helsinki Declaration. Approval for the study was granted by the Ethics Committee of Ankara Numune Traning and Research Hospital.

The study followed a prospective, controlled design and comprised two groups; the test group included 58 eyes of 58 patients newly diagnosed with primary Sjögren syndrome with worsening dry eye test findings and the control group included 45 right eyes of 45 healthy age and gender-matched individuals with no systemic or eye diseases. The PSS group comprised 46 females and 12 males with a mean age of $48.15 \pm 16.34$ years. The control group comprised 35 females and 10 males with a mean age of $44.06 \pm 9.15$ years $(p=0.213)$.

The disease was defined per the 2002 AECG (American-European Consensus Group) criteria for the diagnosis of PSS ${ }^{(15)}$. The 2010 ESSDAl index score was used to determine the systemic activity score of the disease ${ }^{(16)}$. This clinical index score assesses PSS in a standardized manner and classifies disease severity in 12 organ regions. ESSDAl is a physician-based assessment of systemic features and severity and includes kidney, synovitis, vasculitis, lung, skin, musculoskeletal system, and neurological evaluation. Scores $<5$ indicate low disease activity and scores $\geq 5$ indicate high disease activity. Another simple index designed to measure PSS patient symptoms is the EULAR Sjögren's syndrome patient-reported index (ESSPRI) assessed via a survey of patient responses ${ }^{(17)}$. The survey used included three questions that assessed dryness, weakness, and pain in arms and legs during the previous two weeks. The patients marked the scale of the relevant complaint(s) from 0 to 10 and the total score was based on the average of three answers.

All evaluations of the ocular surface were done by one ophthalmologist (DO). The ocular surface disease index (OSDI) questionnaire, osmolarity, schirmer I test with no anesthesia, FBUT, and cornea-conjunctiva staining with lissamine green (van Bijsterveld scoring) were applied to evaluate tear function via a complete ophthalmological examination after PSS diagnosis and the results were graded based on the DEWS report.

Tear osmolarity was measured using the TearLab Osmolarity System (TearLab, San Diego, CA, USA) which automatically collects tears and provides test results.
The OSDI questionnaire consists of 12 items evaluating the symptoms of eye-related irritation and the effect on visual acuity. The Turkish translation of this questionnaire was done by a single physician (DO). The total OSDI score of each patient was calculated as follows; OSDI score $=$ Total score in all answered questions $\times 100 /$ Total number of questions answered $\times 4$. A total score of $\geq 33$ was considered to indicate severity ${ }^{(18,19)}$.

The Schirmer I test was done on the lower third of the lateral bulbar conjunctiva without topical anesthesia and the patients were asked to wait for five minutes and blink normally. The results were recorded in millimeters $(\mathrm{mm})$.

The fluorescein breakup time (FBUT) test was done using a biomicroscope under cobalt blue light. A fluorescein strip (1\% Biotech ${ }^{\circledR}$, India) was dropped onto the tear film of the patient, who was then told to blink once and not thereafter. The FBUT was recorded as the time in seconds from the blink until the appearance of the first break spot in the fluorescein under cobalt blue illumination. The test was repeated a total of three times and the average was considered the final result. Any break of the punctate epithelial defect was not evaluated.

Cornea-conjunctiva staining with lissamine green was done on the lower eyelid of the patients. A lissamine green strip (1.5 mg, Biotech ${ }^{\circledR}$, India) diluted with unpreserved artificial tears was placed in the lateral third of the bulbar conjunctiva. Biomicroscopy was done by a single physician (DO) to obtain the lissamine green staining score. The eye was divided into three sections comprising temporal, nasal conjunctival, and corneal sections, and each area was graded using the van Bijsterveld scoring system ( 0 , no staining; 1 , light staining; 2 , moderate staining; 3 , diffuse staining ${ }^{(20)}$. The total stain was rated from 0 to 9 .

Following the DEWS classification, grading was applied at 4 levels $(0=$ mild, $4=$ severe) ( 1$)$. Results of the following evaluations were analyzed together; corneal (from none to severe and punctuate erosions) and conjunctival staining (from none ++ staining), the Schirmer test (from $>10 \mathrm{~mm}$ to $<2 \mathrm{~mm}$ ), the FBUT test (from $>10 \mathrm{~s}$ to $<2 \mathrm{~s}$ ), discomfort, severity and frequency symptoms, visual symptoms (from mild episodic to constant), conjunctival injection (from none to ++ injection), eyelid-meibomian gland findings (presence or absence of meibomian gland disease, trichiasis, keratinization, and symblepharon), corneal-tear signs (presence or absence of filamentary keratitis, mucus clumping, tear debris, and ulceration).

The PSS diagnosis was assessed using the 2002 AECG findings regarding the diagnostic criteria for dry mouth 
and dry eye. Accordingly, salivary gland biopsy, sialography and/or scintigraphy, positive serology, and tests that define tear deficiency are recommended. The ESSDAl activity score is widely used, especially in the treatment plan. Using these criteria scored from 1-19, a score of $<5$ is evaluated as low, $\leq 13$ as medium, and $\geq 14$ as high activity ${ }^{(21)}$. The specificity of these criteria has been reported to be $95.2 \%$ and the sensitivity $89.5 \%{ }^{(15)}$. In the present study, the ESSDAI and ESSPRI were evaluated by a single physician (AO) in the rheumatology department after PSS was first diagnosed per the AECA criteria.

Exclusion criteria were any previous ocular surgery, meibomian gland disease which may cause dry eye, blepharitis, use of topical drops in the previous six months, a systemic disease such as diabetes mellitus, hypertension, other rheumatologic disease, glaucoma, uveitis, or contact lens use.

All data were analyzed using the software Statistical Package for Social Sciences (SPSS Inc., Chicago, IL, USA) 15.0 for Windows. Continuous variables were represented as mean \pm standard deviation and categorical variables as numbers and percentages. Independent samples t-test was used for the comparisons of the means of the patient and control groups. Pearson correlation analysis was performed to determine the association of ESSDAI and osmolarity scores with the other dry eye test parameters. A value of $p<0.05$ was accepted as statistically significant.

\section{RESULTS}

The dry eye test results and ESSDAI and ESSPRI evaluations of the patients are shown in table 1 and correlations of ESSDAI and osmolarity scores with dry eye test results of PSS patients are shown in table 2.

Lissamine green staining scores, osmolarity, schirmer I test scores, and FBUT scores in the PSS group were statistically significantly different from those in the control group $(p=0.001, p=0.001, p=0.041$, and $p=0.036$ respectively).

Significant correlations were found between ESSDAI and lissamine green staining scores, osmolarity, schirmer I test scores, FBUT scores, and DEWS scores $(p=0.001$, $p=0.001, p=0.011, p=0.022$, and $p=0.001$ respectively); similarly, correlations were also found between osmolarity and lissamine green staing score, schirmer 1 test scores, FBUT scores, DEWS scores, and ESSDAI $(p=0.002$, $p=0.018, p=0.044, p=0.003$, and $p=0.001$ respectively).
Table 1. Comparison of the dry eye and ESSDAl test scores in the PSS and control groups

\begin{tabular}{|c|c|c|c|}
\hline & $\begin{array}{l}\text { PSS group } \\
(n=58)\end{array}$ & $\begin{array}{l}\text { Control group } \\
\qquad(n=45)\end{array}$ & $\mathbf{p}$ \\
\hline OSDI score & $18.56 \pm 16.09$ & $19.92 \pm 7.16$ & 0.103 \\
\hline FBUT (sn) & $4.51 \pm 2.89$ & $10.20 \pm 2.39$ & $0.036^{*}$ \\
\hline Schirmer I test $(\mathrm{mm} / 5 \mathrm{~s})$ & $3.51 \pm 3.18$ & $9.77 \pm 2.30$ & $0.041^{*}$ \\
\hline Lissamine green staining score (0-9) & $2.17 \pm 2.76$ & 0.00 & $0.001^{*}$ \\
\hline Osmolarity (mOsm) & $306.48 \pm 19.35$ & $292.54 \pm 10.67$ & $0.001^{*}$ \\
\hline DEWS score (0-4) & $2.15 \pm 0.98$ & - & \\
\hline ESSDAl score (0-19) & $11.18 \pm 4.05$ & - & \\
\hline ESSPRI score (0-10) & $5.20 \pm 2.63$ & - & \\
\hline
\end{tabular}

${ }^{*} \mathrm{p}<0.05$, independent samples t-test.

Table 2. Correlations of ESSDAI and osmolarity scores with dry eye test scores in PSS patients

\begin{tabular}{lcccccc} 
& \multicolumn{2}{c}{ ESSDAI $(\mathbf{r})$} & & \multicolumn{2}{c}{ Osmolarity } \\
\cline { 2 - 3 } \cline { 6 - 7 } & & $\mathbf{r}$ & $\mathbf{p}$ & & $\mathbf{r}$ & $\mathbf{p}$ \\
\hline OSDI score & 0.151 & 0.125 & & 0.171 & 0.163 \\
FBUT (s) & -0.586 & $0.022^{*}$ & & -0.533 & $0.044^{*}$ \\
Schirmer I test (mm/5 s) & -0.671 & $0.011^{*}$ & & -0.679 & $0.018^{*}$ \\
Lissamine green staining score (0-9) & 0.683 & $0.001^{*}$ & & 0.821 & $0.002^{*}$ \\
Osmolarity (mOsm/L) & 0.879 & $0.001^{*}$ & & - & - \\
DEWS score (0-4) & 0.951 & $0.001^{*}$ & & 0.936 & $0.003^{*}$ \\
ESSDAI & - & & & 0.879 & $0.001^{*}$ \\
ESSPI & 0.250 & 0.59 & & 0.293 & 0.056 \\
\hline
\end{tabular}

${ }^{*} \mathrm{p}<0.05$, Pearson correlation analysis.

\section{DISCUSSION}

The ESSDAl was used to evaluate disease severity in PSS patients because of its recent extensive use in clinical practice. In a comprehensive review of the use of ESSDAl by Seror et al., the authors confirmed the validity of ESSDAI in most clinical studies and in ongoing clinical trials $^{(22)}$. In an analysis of 195 patients by Risselada et al., the value of the ESSDAl in clinical practice was critically appraised for the first time. The ESSDAl scores were found to be low and stable in the general population and were recommended for their ability to capture disease activity in patients in whom individual changes may be present $^{(23)}$.

The OSDI questionnaire addressing daily complaints of patients and their effect on visual acuity, eyelid examination, FBUT, Schirmer test, and cornea-conjunctiva staining with lissamine green or rose bengal are applied to evaluate dry eye in PSS patients. However, low specificity is a problem in these tests due to differences between examining physicians ${ }^{(1)}$. Occassionally, the patient symp- 
toms may not be consistent with their findings. Therefore, tear osmolarity is considered a reliable diagnostic marker of dry eye disease ${ }^{(24-27)}$. The TearLab Osmolarity system automatically collects tears and generates a numerical value. Several studies have indicated that dry eye severity and tear osmolarity are correlated ${ }^{(27-28)}$. Bunya and et al. found that ocular osmolarity and Schirmer I test scores were correlated with dry eye symptoms in a study of PSS patients ${ }^{(29)}$. Kim et al. determined that mean osmolarity was $311.1 \pm 16.4 \mathrm{mOsm} / \mathrm{L}$ and found a positive correlation with the OSDI score, a negative correlation with the Schirmer test scores, and no significant correlation with FBUT scores in PSS patients ${ }^{(30)}$. In the present study, osmolarity was determined to be 306.48 $\pm 19.35 \mathrm{mOsm} / \mathrm{L}$ and was found to be statistically significantly positively correlated with the lissamine green staining scores, DEWS scores, OSDI scores, and ESSDAl scores, and negatively correlated with the Schirmer I test scores and FBUT scores. There were differences between the PSS group and the control group in terms of the FBUT and Schirmer test scores but there were no differences in the OSDI test scores. It is also notable that the osmolarity, Schirmer test scores, FBUT scores, and lissamine green staining scores were higher in PSS eyes, and this emphasizes the reliability of these tests.

Although PSS may occur at any age, the mean age of onset is between 40-50 years and the female:male ratio is $9: 1^{(31,32)}$. In the present study, the female:male ratio was 3.8:1, which may be due to the study being conducted on patients recently diagnosed with PSS.

To the best of our knowledge, the present study is the first to demonstrate a correlation of ESSDAl with eye test findings. We found no correlation of ESSDAl with OSDI scores, FBUT scores, or Schirmer I test scores, and a positive correlation of ESSDAl with the lissamine green staining scores, osmolarity, and DEWS scores. Further, there were no correlations of ESSPRI or ESSDAl with osmolarity.

\section{REFERENCES}

1. Design and conduct of clinical trials: report of the Clinical Trials Subcommittee of the International Dry Eye WorkShop (2007). Ocul Surf. 2007;5(2):153-62. Review.

2. Craig JP, Nelson JD, Azar DT, Belmonte C, Bron AJ, Chauhan SK, et al. The TFOS Dry Eye Workshop Il: executive Summary. Ocul Surf. 2017;7:30214-8.

3. Stern ME, Beuerman RW, Fox Rl, Gao J, Mircheff AK, Pflugfelder SC. The pathology of dry eye: the interaction between the ocular surface and lacrimal glands. Cornea. 1998;17(6):584-9.
4. Pflugfelder SC, Solomon A, Stern ME. The diagnosis and management of dry eye: a twenty-five-year review. Cornea. 2000;19(5): 644-9.

5. Stern ME, Gao J, Siemasko KF, Beuerman RW, Pflugfelder SC. The role of the lacrimal functional unit in the pathophysiology of dry eye. Exp Eye Res. 2004;78(3):409-16.

6. De Paiva CS, Corrales RM, Villarreal AL, Farley WJ, Li DQ, Stern ME, et al. Corticosteroid and doxycycline suppress MMP-9 and inflammatory cytokine expression, MAPK activation in the corneal epithelium in experimental dry eye. Exp Eye Res. 2006;83(3): 526-35.

7. Zhao J, Kubo S, Nakayamada S, Shimajiri S, Zhang X, Yamaoka K, et al. Association of plasmacytoid dendritic cells with B cell infiltration in minor salivary glands in patients with Sjögren's syndrome. Mod Rheumatol. 2016;26(5):716-24.

8. Szabo K, Papp G, Dezso B, Zeher M. The histopathology of labial salivary glands in primary Sjögren's syndrome: focusing on follicular helper T cells in the inflammatory infiltrates. Mediators Inflamm. 2014;2014:631787.

9. Christodoulou MI, Kapsogeorgou EK, Moutsopoulos HM. Characteristics of the minor salivary gland infiltrates in Sjögren's syndrome. J Autoimmun. 2010;34(4):400-7.

10. Fox PC. Autoimmune diseases and Sjogren's syndrome: an autoimmune exocrinopathy. Ann N Y Acad Sci. 2007;1098(1):15-21.

11. Dafni UG, Tzioufas AG, Staikos P, Skopouli FN, Moutsopoulos HM. Prevalence of Sjögren's syndrome in a closed rural community. Ann Rheum Dis. 1997;56(9):521-5.

12. Bournia VK, Vlachoyiannopoulos PG. Subgroups of Sjögren syndrome patients according to serological profiles. J Autoimmun. 2012;39(1-2): 15-26.

13. Jones DT, Monroy D, Ji Z, Atherton SS, Pflugfelder SC. Sjögren's syndrome: cytokine and Epstein-Barr viral gene expression within the conjunctival epithelium. Invest Ophthalmol Vis Sci. 1994;35(9): 3493-504.

14. The definition and classification of dry eye disease: report of the Definition and Classification Subcommittee of the International Dry Eye WorkShop (2007). Ocul Surf. 2007;5(2):75-92.

15. Vitali C, Bombardieri S, Jonsson R, Moutsopoulos HM, Alexander EL, Carsons SE, et al.; European Study Group on Classification Criteria for Sjögren's Syndrome. Classification criteria for Sjögren's syndrome: a revised version of the European criteria proposed by the American-European Consensus Group. Ann Rheum Dis. 2002; 61(6):554-8.

16. Seror R, Ravaud P, Bowman SJ, Baron G, Tzioufas A, Theander E, et al.; EULAR Sjögren's Task Force. EULAR Sjogren's syndrome disease activity index: development of a consensus systemic disease activity index for primary Sjogren's syndrome. Ann Rheum Dis. 2010;69(6):1103-9.

17. Seror R, Ravaud P, Mariette X, Bootsma H, Theander E, Hansen A, et al.; EULAR Sjögren's Task Force. EULAR Sjogren's Syndrome Patient Reported Index (ESSPRI): development of a consensus patient index for primary Sjogren's syndrome. Ann Rheum Dis. 2011; 70(6):968-72.

18. Schiffman RM, Christianson MD, Jacobsen G, Hirsch JD, Reis BL. Reliability and validity of the ocular surface disease index. Arch Ophthalmol. 2000;118(5):615-21.

19. Miller KL, Walt JG, Mink DR, Satram-Hoang S, Wilson SE, Perry HD, et al. Minimal clinically important difference for the ocular surface disease index. Arch Ophthalmol. 2010;128(1):94-101.

20. van Bijsterveld OP. Diagnostic tests in the Sicca syndrome. Arch Ophthalmol. 1969;82(1):10-4. 
21. Seror R, Bootsma H, Saraux A, Bowman SJ, Theander E, Brun JG, et al.; EULAR Sjögren's Task Force. Defining disease activity states and clinically meaningful improvement in primary Sjögren's syndrome with EULAR primary Sjögren's syndrome disease activity (ESSDAl) and patient-reported indexes (ESSPRI). Ann Rheum Dis. 2016;75(2):382-9.

22. Seror R, Bowman SJ, Brito-Zeron P, Theander E, Bootsma $H$, Tzioufas A, et al. EULAR Sjögren's syndrome disease activity index (ESSDAl): a user guide. RMD Open. 2015;1(1):e000022.

23. Risselada AP, Kruize AA, Bijlsma JW. Clinical applicability of the EULAR Sjogren's syndrome disease activity index: a cumulative ESSDAl score adds in describing disease severity. Ann Rheum Dis. 2012;71(4):631.

24. Sullivan BD, Crews LA, Sönmez B, de la Paz MF, Comert E, Charoenrook V, et al. Clinical utility of objective tests for dry eye disease: variability over time and implications for clinical trials and disease management. Cornea. 2012;31(9):1000-8.

25. Tomlinson A, Khanal S, Ramaesh K, Diaper C, McFadyen A. Tear film osmolarity: determination of a referent for dry eye diagnosis. Invest Ophthalmol Vis Sci. 2006;47(10):4309-15.

26. Lemp MA, Bron AJ, Baudouin C, Benítez Del Castillo JM, Geffen D,
Tauber J, et al. Tear osmolarity in the diagnosis and management of dry eye disease. Am J Ophthalmol. 2011;151(5):792-98.e1.

27. Schargus M, Wolf F, Tony HP, Meyer-Ter-Vehn T, Geerling G. Correlation between tear film osmolarity, dry eye disease, and rheumatoid arthritis. Cornea. 2014;33(12):1257-61.

28. Miserocchi E, luliano L, Berchicci L, Bandello F, Modorati G. Tear film osmolarity in ocular mucous membrane pemphigoid. Cornea. 2014;33(7):668-72.

29. Bunya VY, Langelier N, Chen S, Pistilli M, Vivino FB, Massaro-Giordano G. Tear osmolarity in Sjögren syndrome. Cornea. 2013;32(7):922-7.

30. Kim M, Kim HS, Na KS. Correlation between Tear Osmolarity and Other Ocular Surface Parameters in Primary Sjögren's Syndrome. Korean J Ophthalmol. 2017;31(1):25-31.

31. Kabasakal Y, Kitapçığlu G, Türk T, Öder G, Durusoy Y, Mete N, et al. The prevalence of Sjögren's Syndrome in adult women. Scand J Rheumatol. 2006;35(5):379-83.

32. Tzioufas AG, Mitsias ID, Mouthsopoulos HM. Sjögren's Syndrome. In: Hochberg MC, Silman AJ, Smolen JS, Weinblatt ME, Weisman MH eds. Rheumatology, 4th ed. Vol. Il, Mosby Elsevier, 2008:1341-52. 